\section{Arts}

The aim of the third conference was to examine the position of the arts student in a society which is apparently becoming more and more technological in emphasis, and in particular to consider the value and relevance of the traditional approach to an arts education.

About forty teachers from grammar and public schools attended this last conference, of which the chairmen were Mr. A. D. C. Peterson, director of the University of Oxford Department of Education, and $\mathrm{Mr}$. K. Charlton of the University College of North Staffordshire.

Other speakers included Prof. W. H. G. Armytage (University of Sheffield), Mr. H. S. Mullaly (British Petroleum), Mr. D. W. Hutchings (University of Oxford), Dr. A. E. Bell (Cheltenham Grammar School), and Mr. Hugh P. Ramage of the Science Masters' Association. The closing address was given by Dr. F. A. Vick, director of the Atomic Energy Research Establishment.

In introducing the conference, Mr. Peterson touched on the very early polarization into 'arts men' and 'science men' that took place in Britain, the almost total exclusion of the resthetic arts from our school syllabuses and the minute resources that were allocated to educational research. But he was primarily concerned with the vital areas of communication and human behaviour, and here he saw serious shortcomings in such fields as mathematics and language teaching.

Mr. Charlton sketched the historical development of the arts education while Prof. Armytage outlined the pressures that were changing our total environment-cheap power, the computer revolution, the growth of the chemical industry and the growing power to manipulate opinion. The employment of arts graduates in a large organization was discussed by Mr. Mullaly, while Mr. Hutchings spoke on the general question of whether science should, or could, be taught to arts students; Mr. Ramage explained the proposals of the Science Masters' Association in this field. Dr. Bell described the work he was already doing in his school, and to wind up the conference, Dr. Vick surveyed and illuminated the outlook and methods that contribute to the scientific imagination.

Though the conference was convinced of the value of an arts education in the formation of values and as a guide to human behaviour in all its complexity and in all fields of human endeavour, it accepted the view that the arts student should be helped towards an understanding of modern science and its methods and philosophy. It deplored the existence of the 'two cultures' in education and called for the elimination of this concept, both in thought and in practice. But the introduction of any serious scientific study into the sixth-form arts curriculum would raise very considerable difficulties of programming and staff and complicate yet further this serious situation in science teaching. In particular, some members of the conference felt that teachers of arts subjects should in some way evolve a negotiating body that could discuss with the Science Masters' Association the possible introduction of scientific studies.

During all three conferences, the theme that emerged was that of 'relevance': not relevance in any narrow vocational or materialist sense but relevance to life as lived in a society where modern science and technology are dominant social forces. It is necessary to understand these forces, whether to co-operate with them or to resist them.

\title{
OCEANOGRAPHY IN LATIN AMERICA
}

$F^{\circ}$ OUR meetings were recently held in Chile concerning oceanography and its research development in Latin America. They were: (1) a Latin American seminar of oceanographic studies; (2) the second Latin American Symposium on Plankton; (3) a meeting of directors of Latin American coastal laboratories; and (4) a regional training course on marine biology. They were organized jointly by the Unesco Science Co-operation Office for Latin America and, in the case of (1) and (2), the University of Concepción, and, for (3) and (4), the University of Chile, and held, respectively, in the General Biology Laboratory (Concepción) and Marine Biology Station (Montemar).

Thirty-seven Latin American scientists participated, coming from Mexico, Colombia, Venezuela, Brazil, Uruguay, Argentina, Chile, Peru and Ecuador. Observers were present including: Dr. D. L. Ray, from the National Science Foundation (United States); Dr. P. Dohrn, from the Stazione Zoologica di Napoli (Italy); Dr. W. Branhorst, chief of the Federal Republic of Germany Technical Assistance Programme to Chile; and Dr. F. Ottmann, from the Institute of Marine Biology, Recife (Brazil). Dr. R. Margaleff (Spain) was present, by special invitation, at the Symposium on Plankton. In the first meeting, Dr. P. Roa Morales (Venezuela) was elected chairman for the Abiotic Section, and Dr. F. de Buen (Chile) for the Biological Sections and also for the directors' meeting. Dr. R. Margaleff (Spain) was invited to act as chairman of the Symposium on Plankton, and for the regional training course Dr. F. de Buen and Dr. E. Rioja (Mexico) acted as co-directors, with the assistance of scientists from Mexico, Chile, Uruguay, Argentina and Brazil. (This course was attended by more than twenty students from Latin American countries.) In all these meetings, Dr. H. Ferrando (Uruguay) acted as secretary.

The main purpose of these meetings was to make an evaluation of the actual standing of research in marine sciences in Latin America in the light of what has been accomplished; accordingly, a series of valuable reports was submitted by leading scientists from Latin America, covering the different disciplines of marine sciences. It was also felt that some decision should be taken so as to increase the existing knowledge through research and training, primarily on a co-operative regional basis.

Among the most outstanding points arising from the adoption of resolutions and recommendations made at the meetings were the following:

(1) The creation of a Latin American Council on Oceanography, with the election of its steering committee composed of leading marine scientists from Mexico, Venezuela, Uruguay, Argentina, Chile and Brazil, under the chairmanship of Dr. F. de Buen. 
This Council will become a permanent Latin American Council once the necessary official steps have been taken throughout all the Latin American countries; the secretariat will be located at the Unesco Science Co-operation Office for Latin America, Bulevar Artigas 1320, Montevideo, Uruguay.

(2) The commencement of research programmes on a regional co-ordinated basis. Seven projects were presented, and the necessary measures are being taken at the present moment for the co-ordination of more than one, in which the existing marine biology laboratories and oceanographic institutes will integrate a close network with the help of the means that the hydrographic naval services may provide.

(3) The publication of a Latin American Directory of Oceanographic Institutions and Scientists so as to increase and encourage the exchango of scientists, students, information and material, with the Unesco Science Co-operation Offico acting as a 'clearing house'.

(4) The unification and standardization of methods and equipment in marine research.

(5) Unesco was asked to organize in 1962 a twomonths' training course in physical oceanography. The Oceanographic Institute of the University of Oriente (Venezuela) extended an invitation to act as host, and the Brazilian Navy offered its oceanographic vessel, Almirante Saldanha, to make a training cruise as a complement of the course.
(6) Unesco was asked to organize in 1962 a regional Symposium on Biogeography and Marine Organisms, so as to study the geographical distribution of marine organisms and the effects on them, of the physicochemical condition of water masses, and its dynamics. The National Museum of Natural History "Bernardino Rivadavia" (Argentina) made an official invitation to act as host during the celebration of its one hundred and sixtieth anniversary.

(7) Uneseo was asked to organize in 1962 a meeting of deans of science faculties of Latin American Universities, so as to increase the scholastic standards needed for the encouragement of marine scientists through the re-organization and modification of their curricula and plans of study.

Preparations for the organization of the last three items have already been started by Unesco Science Co-operation Office. In an effort to compile bibliographies of research work carried out in Latin America on the marine sciences, which already begins to show profitable results, each scientist presont at the mecting will be contributing in his own specific field. To help this aspect of the marine sciences in Latin America, the Council requests all scientists and institutions to send copies of reprints to the Unesco Science Co-oporation Office for Latin America, Casilla de Correo 859, Montevideo, Uruguay, whenever they deal with any aspect of the marine sciences in Latin America.

\section{CHEMICAL APPLICATIONS OF DIFFRACTION METHODS}

$\mathbf{T}^{\mathrm{T}}$ is nearly fifty years since von Laue, Friedrich and Knipping first diffracted X-rays from a crystal. Since then, diffraction methods, based on X-rays or on analogous but less widely used techniques, have been applied to the investigation of a variety of chemical problems. The scope of these was the subject of a short course of lectures and discussions under the title "Chemical Applications of Diffraction Methods" held in the Department of Chemical Technology, Bradford Institute of Technology, during November 24-25, 1961. About forty graduates from industry, the universities and technical colleges attended.

Participants were welcomed by the head of the Department, Dr. R. L. Elliott, who took the chair for the opening session. In his introductory talk on symmotry and diffraction, Dr. J. H. Robertson (University of Leeds) presented the concept of symmetry in an informal way, in terms of familiar everyday objects, beforc outlining the types of symmetry appropriate respectively to the external and internal form of erystals. After giving a more formal treatment of the diffraction process, Dr. Robertson showed that, while knowledge of crystal symmetry alone can sometimes yield molecular information directly, it is commonly a preliminary to more detailed X-ray crystal analysis. This was the subject of the talk by Dr. D. W. Jones (Bradford Institute of Tcchnology), who examined the experimental X-ray data available from singlo crystals and stressed the phase problem intrinsic in structure analysis. Tho isomorphous salt and heavy-atom methods of tackling this wore illustrated by the closely related structures of the alkali motal aminedisulphonates; detailed X-ray refinement of the ealcium orthophosphate structures demonstrated the difficulty of locating hydrogen directly in the presence of heavier atoms. Often, however, the approximate stereochemistry of a moleculo could be established on the basis of photographic X-ray data alone and without recourse to large-scale computing. The idealizod single erystal X-ray analysis method had links, on one hand, with the study of less well-ordered samples by X-rays and, on the other, with diffraction by electrons and neutrons.

The second session was devoted to more specialized applications of X-ray diffraction. In his talk on fibre crystallography and X-ray crystallinity, Dr. D. R. Holmes (Central Electricity Research Laboratories, Leatherhead) recommended the use, where feasible, of doubly oriented specimens, the tilted 'crystal' mothod, equi-inclination photography and cylindrical cameras in order to minimize the effect of the paucity of wide-angle X-ray data available from a fibre. Even so, the agreoment between sets of X-ray intensities measurod by different workers for cellulose, for example, was somewhat disappointing. The fairly complete molecular model that can result from the study of well-ordered polymors was illustrated by the structures of silk and polyethylene terephthalate. For the measurement of X-ray crystallinity, however, the orientation occurring in many industrial fibres could be a handicap, and Dr. Holmes mentioned a device for mechanical random. ization about two axes. Because of its ready application to short-term industrial problems, the X-ray powder method is probably the most widely used diffraction procedure in applied chemistry and metallurgy. Dr. K. W. Andrews (United Steel Companies, Ltd., Rotherham) described experimental techniques 